\title{
EVALUATING EFFECTIVENESS OF GRINDING PROCESS GRAIN MATERIALS
}

\author{
Ramil Iskenderov, Anatoly Lebedev, Anton Zacharin, Pavel Lebedev \\ Stavropol State Agrarian University, Russia \\ iskenderov_ramil@inbox.ru
}

\begin{abstract}
The design features of shredders and the type of feedstock have a decisive influence on the quality of the finished product and on the leveling of its granulometric composition. Inadequate quality of prepared feed reduces the effectiveness of using forage grains up to $30 \%$. For various species and age categories of animals and poultry, it is necessary to produce mixed fodders, nutritionally balanced and various in particle size. This article presents a methodology for assessing the efficiency of the process of grinding grain materials based on the actual performance of technological processes. The possibility of evaluating this indicator is achieved due to the differentiation of the mass of the finished crushed product into three fractions: the required size, non-hammer and grind, and the last two of them are substandard, requiring further impact on them. The proposed theoretical model characterizes this process from the qualitative aspect of its implementation. On the example of grinding characteristics of grain crusher "Zubrenok" it is shown how the technological process of grain grinding is estimated in accordance with the proposed method and allowed to detect about $28 \%$ of the substandard fraction in the finished product, when its grinding module $M=2.1 \mathrm{~mm}$ corresponds to the zootechnical requirements of 1.8-2.6 mm. For comparison, the process of grinding grain in the hammer and rotor crushers and the correspondence of the State Standard product obtained in them are considered. Unlike the standard methods of evaluation by the grinding module and the degree of grinding, the actual effectiveness is more sensitive to changes in the granulometric composition of the finished crushed product.
\end{abstract}

Keywords: grinding process, the actual efficiency, non-grinding, grinding, required size, rotary crusher.

\section{Introduction}

To ensure a better feed intake, all the nutrients in their composition must be given to animals in the most digestible form. There are mechanical, thermal, chemical and biological methods of preparation and preparation of feeds for feeding. The main operations of preparation of animal feed are cleaning, grinding, dosing and mixing. Grinding creates the conditions for the implementation of all subsequent technological operations [1-5].

The science and practice of feeding animals and poultry has established that the effectiveness of mixed fodders depends not only on its balance in nutritional composition, the type and age of animals, but also on the particle size of the mixed fodders. Currently, there are both different studies and international norms that recommend and regulate the quality, size, nutritional content and other properties of the feeds, respectively [6-8].

At the beginning of the new century, the Kansas State University in the USA conducted many studies to study the effect of the size of feed particles on the change in the productivity of pigs. It was found that young pigs, in contrast to pigs on growing and fattening, better chew food. The most preferred group of animals for obtaining a finer grinding feed is, therefore, pig fattening. Efficiency of feed improves as a result of improved digestibility of nutrients. In this case, the average daily weight gain of animals from reducing the size of the feed particles does not suffer. Typically, reducing the particle size reduces feed intake. Nevertheless, the optimum particle size is 500-700 microns. In pigs that received a grain portion of the feed, ground to a particle size of 500 microns, the efficiency of the feed increased by $6 \%$, in contrast to the pigs that consumed grains with a particle size of 900 microns. On the other hand, when the particle size of the crushed grain is reduced (for example, from 700 to 500 microns), productivity in feed production is reduced. To decide on the optimal size of the feed particles, you need to find a compromise between the degree of digestibility of the feed and the reduction in the productivity of the shredder. According to researchers at the Kansas State University, the optimal size of the grain particle feed is 700 microns $(0.7 \mathrm{~mm})$, which achieves a balance of swine productivity and the efficiency of the feed mill. But with fine grinding, along with spraying the feed components, its effectiveness decreases because of the rapid passage of finely divided particles through the digestive tract, diseases that occur in animals and birds, and feed losses [6;7].

The size of the feed particles is different for all species and age categories of animals. The requirements of the national standards of the Russian Federation apply to mixed fodder, obtained by 
grinding feed pellets to particles of a given size, and intended for feeding to agricultural animals $[4 ; 8 ; 9]$.

As the analysis shows, modern research does not fully correspond to zootechnical norms and current standards. So, according to scientists from the United States, the size of fodder particles for pigs is in the range of 500-900 microns, i.e. $0.5-0.9 \mathrm{~mm}$, and according to State Standard R 543792011 the same feed should not contain more than $18-20 \%$ of particles less than $1 \mathrm{~mm}$ of the total mass. Such inconsistency can be explained by different conditions of the animals, their type and age category, climatic conditions, farm volumes, feed varieties, types of machines for preparing feeds, and many other factors that determine the final requirements for the size of the particles of feeds received and their homogeneity.

\section{Materials and methods}

The initial data for the calculation and selection of the grain shredder are the type and quantity of the processed product to a given grinding module, depending on the species of the animals and their age category. In this sense, all shredders (crushers, mills, roller machines, etc.) should be universal. They must grind various types of feed materials and be able to regulate their degree of grinding. This is achieved by reconfiguring the equipment by changing the sieves, hammers, adjusting the speed of the working bodies, working clearances, changing the feed and other methods available in a particular design.

However, special attention in developing approaches to the efficiency and quality of the pulverized mass is deserved both by the method and by the evaluation of the work done by the grinders themselves. The methods used for estimating the degree of grinding, the grinding module, in our opinion, are rather crude and do not reflect the real picture of the realized processes. This is a weighty and relevant argument in the development of a method for evaluating the grinding process based on the modernization of existing ones and the introduction of new evaluation criteria, as well as the real ranges for their variation. According to State Standard, the fraction less than $1 \mathrm{~mm}$ should not exceed $18-20 \%$ for most agricultural animals and poultry, regardless of their age category. At the same time large, medium and fine grinding is necessary for them, the value of which, according to the existing method of sieve analysis, is determined by the average value of the fractions of each range of fractions. In our opinion, this approach does not reflect the real picture of this important technological process.

On the basis of the analysis of earlier performed works, the technique for evaluating technical means when selecting them [1] deserves attention, the index of $F_{p i}$ - the actual performance of the $i$-th object:

$$
F_{p i}=\frac{Y_{i}}{\Omega_{i}},
$$

where $Y_{i}-$ reliability of the technological process;

$$
\Omega_{i}=1-Y_{i} \text { - unreliability of the technological process. }
$$

The physical meaning of the $F_{p i}$ indicator is that it shows how many reliable applications the object has for each unreliable, consistent and inconsistent with the established requirements, i.e. actual or actual result. It can be used to evaluate a variety of technological processes $[1 ; 2]$.

Regardless of the form of ownership and the size of the enterprise with the established structure of the herd and the type of animals, the grinding devices must ensure that the specified amount of work $V_{t r}$ is performed with the required quality determined by the grinding module $M$ or the degree of grinding $\lambda$. Thus, a grinding machine for providing, for example, a daily rate should have a capacity:

$$
Q=\frac{V_{t r}}{t_{r}},
$$

where $t_{r}$-duration of the net work of the crusher, h.

According to the current procedure, if the resulting grinding module $M$ is within the specified range, the entire volume $V_{o}$ is considered suitable for further use. However, practical experience and 
additional studies [2] show that when working shredders (especially hammer crushers), a rather large number of dust particles appear, which impose additional requirements for the microclimate in the premises. But on the other hand, they can worsen the processes of digestion of animals or cause losses during transportation, handling and transportation operations.

The methodological approach to the evaluation of agricultural processes $[1 ; 3 ; 5]$ and the theoretical analysis [2] showed that among the main factors affecting the efficiency of the grinding process, we can distinguish: the type of machine used; the type of material to be crushed with its inherent physicomechanical properties and the way it is divided into parts. This determines the energy characteristics of $N_{y}$ and the productivity of the crusher $Q$, as well as the quality of the crushed grain obtained, Fig. 1.

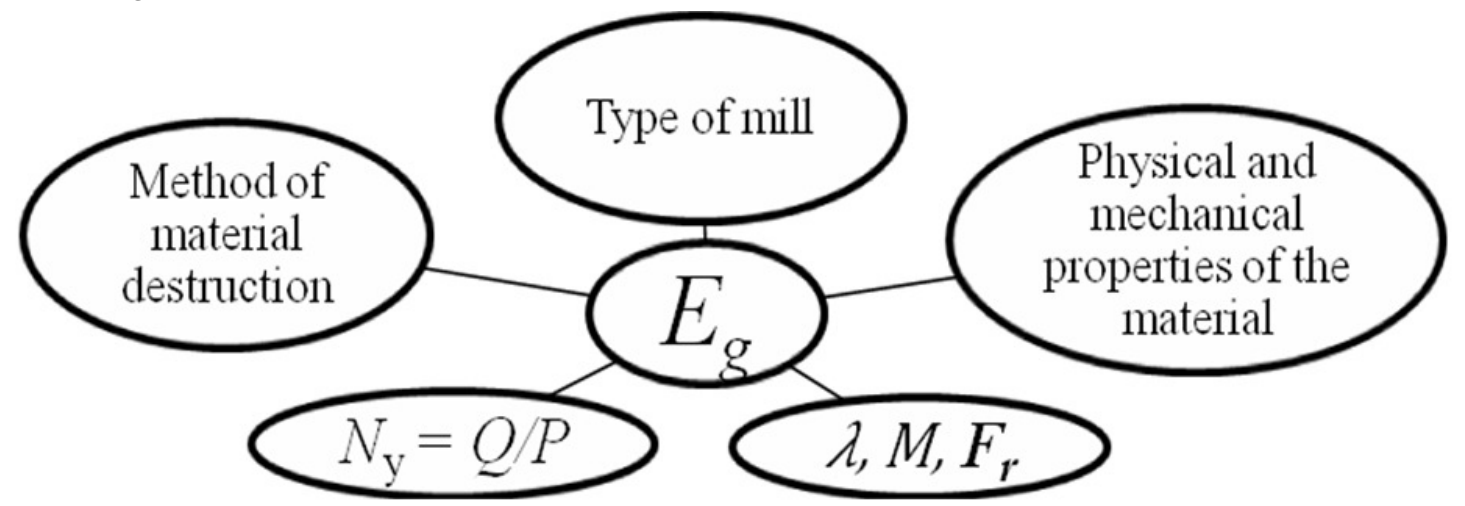

Fig. 1. Factors on which efficiency of grinding depends

As can be seen in the figure, the efficiency of grinding is represented by the complex indicator $E_{g}$, which takes into account not only the degree of refinement of $\lambda$, the grinding module $M$, the energy unit costs $N_{\mathrm{y}}$, including the productivity $Q$ and the required power $P$, but also the actual productivity of the freezing process:

$$
E_{g}=f\left(N_{y}, Q, P, \lambda, M, F_{r}\right) .
$$

Thus, the efficiency of grinding according to the proposed method is estimated by each of the six proposed indicators separately, or by some coefficient that takes them into account in the complex.

Since, the process of separation of the material into parts is of a probabilistic nature, and by analogy with [1] it can be estimated as an indicator of the actual productivity of $F_{r}$. Therefore, we decided to divide the volume of grinding $V_{o}$ into three fractions: a non-grinding $V_{r}$, a milled (grinding) $V_{n}$ and a fraction corresponding to the zootechnical requirements $V_{t r}$ :

$$
V_{o}=V_{n}+V_{t r}+V_{r} .
$$

Then, as applied to the process of grinding grain materials:

$$
F_{r}=\frac{H_{i}}{1-H_{i}},
$$

where $H_{i}$ - reliability of grinding (required size);

$1-H_{i}$ - unreliability of grinding (grinding and non-grinding).

The reliability of the grinding process can be represented by the ratio of the mass of the fraction of the corresponding given degree of grinding to the total ground mass:

$$
H_{i}=\frac{V_{t r}}{V_{o}} .
$$

A quality assessment of the actual performance of the grinding process $\left(F_{r}\right)$ of grain materials can be presented in the following form:

$$
F_{r}=\frac{V_{t r}}{V_{n}-V_{r}},
$$


Consider, for example, the grinding characteristics of the hammer crusher "Zubrenok" when grinding feed grain to a bird $(M=1.8-2.6 \mathrm{~mm})$, constructed on the basis of sieve analysis data, three indicators $M, \lambda, F_{r}$, assessing the quality of the grinding produced.

In Figure 2 the analysis of the distribution of the crushed fractions of the finished product with conventional indicators showed that the grinding module was $M=2.1 \mathrm{~mm}$, the degree of crushing was $\lambda=2.2$. When evaluating the obtained grinding result by the proposed method, it is evident that, according to the grinding characteristic, the milled and ground $\left(V_{r}+V_{\mathrm{n}}\right)$ are $27.9 \%$, and the required fraction is $72.1 \%$ of the total weight of the finished product $V_{\mathrm{o}}$. In this case, using formula (7), we obtain an index of the actual efficiency of the grinding process $F_{r}=2.6$. It should be noted that the obtained value of the grinding module $M=2.1 \mathrm{~mm}$ corresponds to the zoo technical requirements.

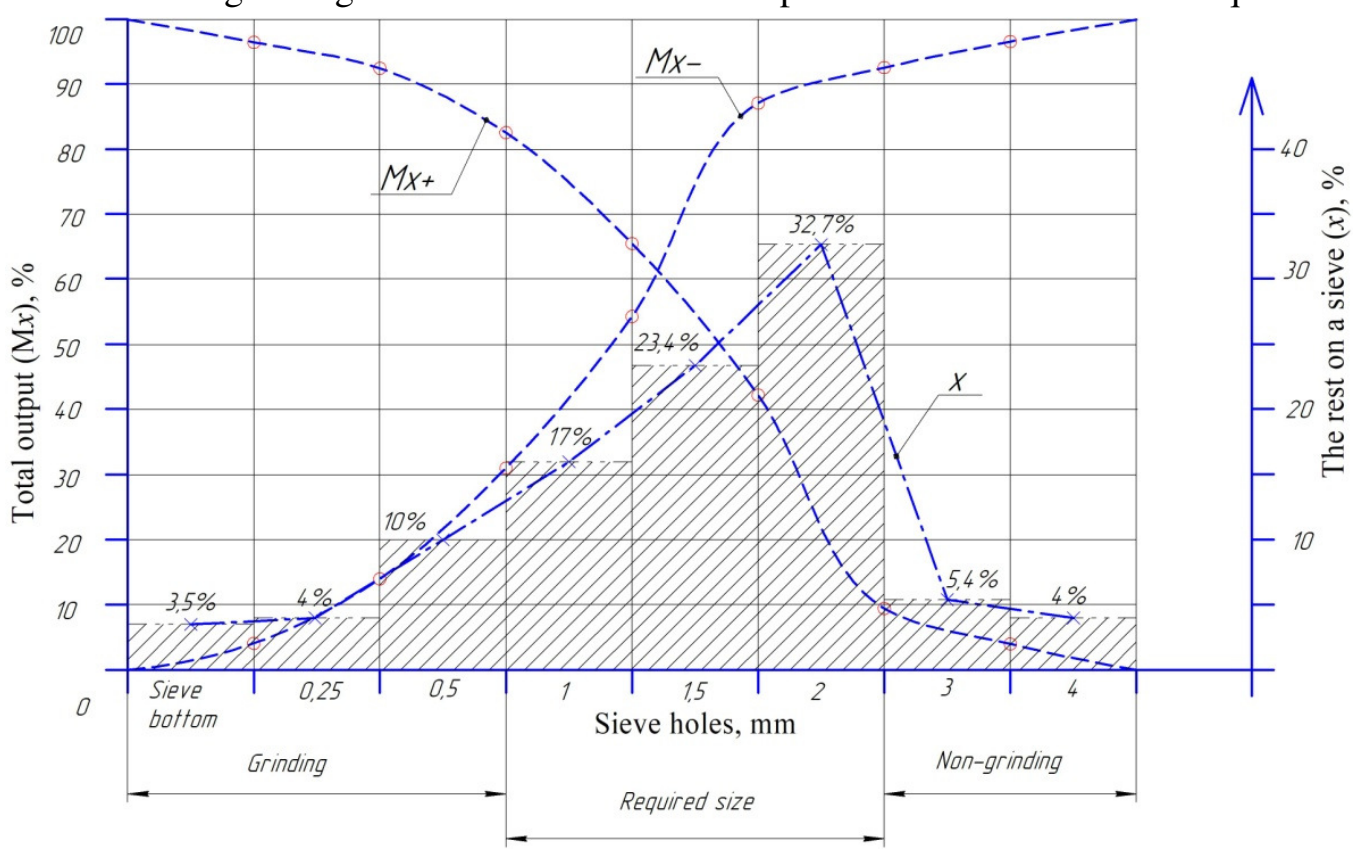

Fig. 2. Grinding characteristic of coarse grinding produced in grinder "Zubrenok": $M_{x}$ - partial distribution of fractions, $M_{x+}, M_{x-}$ - total yield in plus and minus

According to the State Standard R 54379-2011, to ensure average grinding $M=1.8-2.6 \mathrm{~mm}$, the homogeneity of the particle size distribution should be within not less than $80 \%$, or the fraction of substandard fractions satisfying the minimum quality index of the finished product should not exceed $19 \%$. Guided by the requirements of the State Standard, we will determine the normal value of the indicator of the actual effectiveness of the process of grinding grain materials by any type of shredder. It should be at least $F_{r}=4.26$.

As is known, the grinding module is determined by the species of animals and their age category, and therefore the intensity of the development of the organism, the absence of diseases, and the energy efficiency of technological machines will be determined by the equalization of the granulometric composition of the crushed grain. The indicator of actual performance in this case is not only more informative, but also more objective in assessing technical facilities and technological processes in general.

Transforming equation (5) with allowance for (6) we obtain:

$$
V_{t r}=\left(\frac{1}{F_{r}+1}\right) .
$$

Equation (8) can be used to determine the additional volume of work in order to provide the zoo technical requirements for the size of the feed, according to the initial data in this case:

$$
\Delta V=\frac{V_{t r}}{F_{r}} .
$$


In addition, using this estimate and believing that the factions of the finished product that are incompatible with the zoo technical requirements cannot be grinding or non-grinding, they can be excluded from the calculation of the actual volume of fodder mass meeting the specified requirements. Then the actual required volume of the product to ensure the initial conditions will be:

$$
V_{f . t r}=\frac{V_{t r}}{F_{r}}+V_{t r}
$$

This means that to the mass of grain materials corresponding to the specified particle size $V_{t r}$, it is necessary to add an additional part $\Delta V$ to provide the livestock with the necessary nutrients. The value of the additional weight of the feed depends on the indicator of the actual effectiveness of the process. The higher it is, the less additional mass of feed is required, thus the amount of grinding work will also be less.

Considering the equation (4), which corresponds to the mass balance of the finished product of the shredder, it can be stated that it is possible to replenish the missing mass of feed by grinding the non-hummock $V_{n}$. This involves additional costs of resources, time and energy needed to separate this part and re-grind the source material. This operation is performed several times. Equating equations (5) and (10) under the condition that the volume of work performed in the limit must correspond to the given $V_{f . t r}$, and carrying out some transformations, we obtain:

$$
F_{r}=\frac{1}{I_{r}+I_{n}},
$$

where $I_{r}=\frac{V_{r}}{V_{t r}}-$ index of the ratio of the re-milled grain mass to the given one;

$$
I_{n}=\frac{V_{n}}{V_{t r}}-\text { index of the ratio of the undersized grain mass to the given one. }
$$

Dependence (11) emphasizes the advantages of the proposed method and allows not only to assess the actual effectiveness of the grinding process, but also gives recommendations for improving the efficiency of this process. This is possible due to the decrease of the In index and the minimization of the $I_{r}$ index, which in aggregate will lead to an increase in the $F_{r}$ index and will allow to keep the actual costs at a minimum level with an almost $100 \%$ compliance of the crushed mass by the qualitative criterion, that is, the equalization of the granulometric composition of the crushed grain material.

For the production test for the hammer crusher of the "Zubrenok" model, new hammers and sieves with a diameter of $3.5 \mathrm{~mm}$ were installed for the preparation of feed for poultry, which consisted of $35 \%$ barley, $17 \%$ oats, $24 \%$ wheat and $24 \%$ maize. Within 35 days, after each working week, we took samples of the ground mass of a $5 \mathrm{~kg}$ grain mixture. The weekly feeding of mixed fodder according to the needs of the peasant farm was $625 \mathrm{~kg}$. Similar tests were carried out and based on the prospective design [10] of a horizontal rotary crusher.

\section{Results and discussion}

Let us compare the obtained data on the diagram of the distribution of the finished product in 3 fractions in Fig. 3.

During the period of the experiment on the hammer crusher "Zubrenok" the amount of pulverized mass corresponding to the required grind size did not exceed $72 \%$. In this case, it is possible to regrind the chopper repeatedly, but this is accompanied by an additional amount of work and additional costs. Particles measuring less than $0.25 \mathrm{~mm}$, averaged $24 \%$ for the entire experiment.

For one ton of re-milled product, the fraction of required size averaged $961 \mathrm{~kg}$ in the rotor and $721 \mathrm{~kg}$ in the hammer mill. The analysis of the average parameters of the crushers showed that:

1. Particles smaller than $0.25 \mathrm{~mm}$ in the rotary chopper make up only $3.9 \%$, which is 4.5 times less than in the hammer mill; 
2. The fraction of the required size on the average is $96.1 \%$ versus $72.1 \%$ in favor of the rotor crusher of the proposed design, and only a short crumb was present in the "Zubrenok" hammer mill.

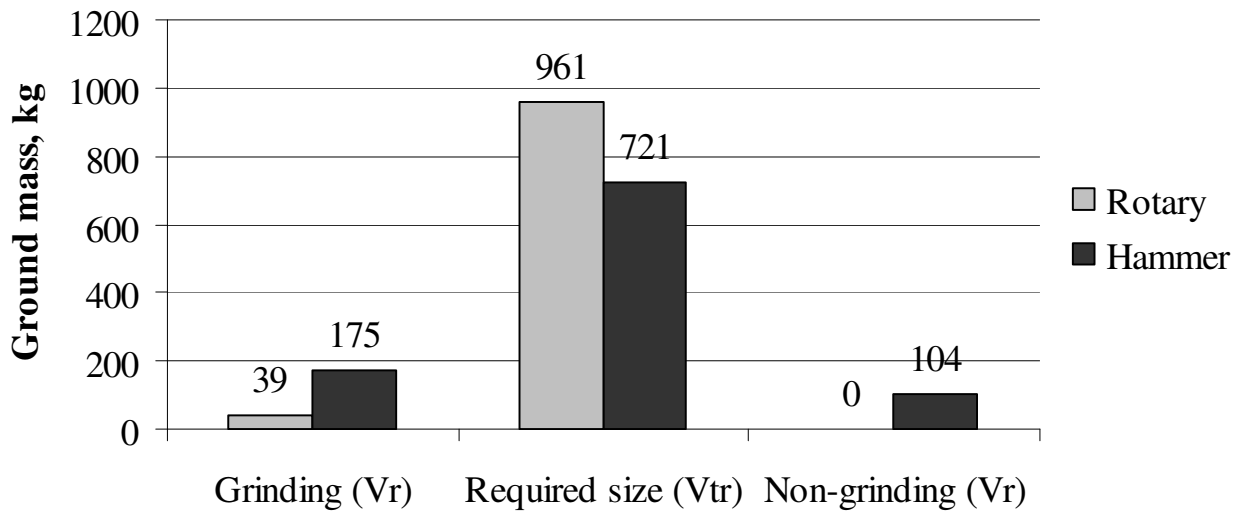

Fig. 3. Comparison of distribution of ground mass

With a milling degree of 1.7 and 1.9 , a grinding module of $2.5 \mathrm{~mm}$ and $2.1 \mathrm{~mm}$, in a rotor and hammer mill, respectively, the crushed grain corresponds to zoo technical requirements and a specified grinding of 1.8-2.6 mm.

- However, when compared with the actual performance indicator, it is evident that in the hammer mill this value is $F_{r}=2.6$, which indicates the presence of $27.9 \%$ unconsolidated fractions in the crushed grain mixture;

- According to the State Standard R 54379-2011, to ensure the average grinding $M=1.8$ $2.6 \mathrm{~mm}$, the homogeneity of the particle size distribution should be within the range of not less than $80 \%$, and $F_{r}$ should be at least 4.26 .

\section{Conclusions}

1. The proposed method makes it possible to assess the quality of the grinding process by a more informative index of actual productivity (in comparison with the degree of grinding and the grinding module).

2. This technique can be applied to other technological processes of grinding, where the specified quality plays a key role and determines the energy intensity, labor intensity, productivity and the cost of production.

3. For homogeneity size of the particles of not less than $80 \%$ when grinding grain materials $F_{\mathrm{r}}$ should be at least 4.26 .

\section{References}

[1] Лебедев, А.Т. Ресурсосберегающие направления повышения надежности и эффективности технологических процессов в АПК (Resource saving of a direction of increase of reliability and efficiency of technological processes in agrarian and industrial complex). The monograph. Stavropol: Монография. Ставрополь. 2012. 376 p. (In Russian).

[2] Лебедев А. Т., Валуев Н. В., Искендеров Р. Р. Экспериментально теоретические подходы к оценке эффективности процесса измельчения зерновых материалов (Experiments theoretical approaches to an estimation of efficiency of process of crushing of grain materials). The Bulletin of agrarian and industrial complex of Stavropol Territory: Вестник АПК Ставрополья. 2014. о 2 (14). Pp. 61-64. (In Russian).

[3] Кормановский Л.М. Точные технологии в животноводстве: состояние и перспективы (Exact of technology in animal industries: a condition and prospects). Technics in agriculture: Техника в сельском хозяйстве. № 1, 2004. Pp. 7-9. (In Russian). 
[4] Нормы и нормативы в животноводстве / В.В. Кузнецов, А.И. Баранников, В.Я. Кавардаков и др. (Norms and specifications in animal industries). The scientifically-methodical grant: научно-методическое пособие. Rostov on Don. 2008. 400 p. (In Russian).

[5] Сыроватка В.И. Машинные технологии приготовления комбикормов в хозяйствах (Machine technologies of preparation of mixed fodders on farms). Moscow: ВНИИМЖ. 2010. 248 p. (In Russian).

[6] О положительном влиянии правильного размера частиц корма на продуктивность сельскохозяйственных животных (About positive influence of the correct size of particles of forage on efficiency of agricultural animals). (In Russian). [online] [20.10.2017]. Available at: http://xn--80abjdoczp.xn--p1ai/nauka-i-praktika/kormoproizvodstvo/1828-o-polozhitelnomvliyanii-pravilnogo-razmera-chastic-korma-na-produktivnost-selskohozyaystvennyhzhivotnyh.html.

[7] Wondra, KJ., 1993. Effects of particle size, mill type, and diet form on performance of finishing pigs and lactating sows. M.S. Thesis. Kansas State University, Manhattan, KS 66506.

[8] Good band R.D., Tokach M.D., Nelssen J.L. The effects of diet particle size on animal performance. Feed manufacturing, No 2050. May 1995. Pp. 156-161.

[9] ГОСТ Р 54379-2011. Крупка комбикормовая. Технические условия. (State Standard R 543792011. Mug forage. Specifications.). (In Russian).

[10]Патент №2552958 Российская Федерация, МПК В 02 С 4/10, В 02 С 4/28. Роторная дробилка / А.Т. Лебедев, В.В. Очинский, Р.Р. Искендеров и др. (Patent No 2552958 Russian Federation, B 02 C 4/10, B 02 C 4/28. Rotary crusher). Applicant and the patent owner Stavropol State Agrarian University: заявитель и патентообладатель ФГБОУ ВО Ставропольский ГАУ. The No 2014108154/13 it is declared 03.03.2014. It is published 10.06.2015. Bulletin № 16. (In Russian). 